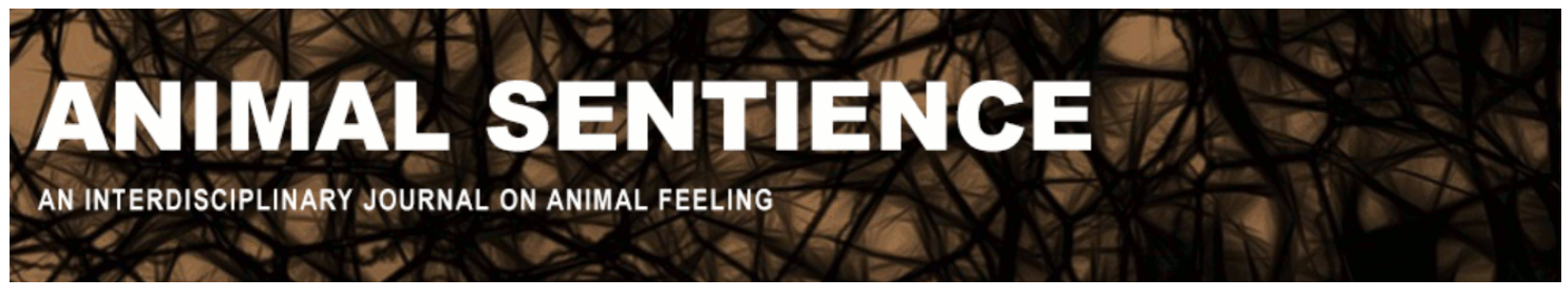

Gray, Joe (2019) Granting political representation to non-humans. Animal Sentience 27(5)

DOI: $10.51291 / 2377-7478.1533$

Date of submission: 2019-11-24

Date of acceptance: $2019-11-30$

(c)

This article has appeared in the journal Animal

Sentience, a peer-reviewed journal on animal

cognition and feeling. It has been made open access,

free for all, by WellBeing International and deposited

in the WBI Studies Repository. For more information,

please contact

wbisr-info@wellbeingintl.org.

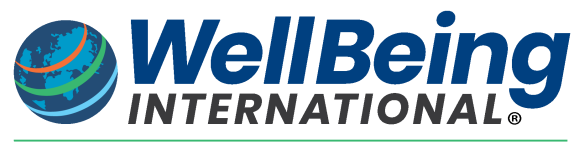

SOLUTIONS FOR PEOPLE, ANIMALS AND ENVIRONMENT 


\title{
Granting political representation to non-humans
}

Commentary on Treves et al. on Just Preservation

\author{
Joe Gray \\ Global Ecocentric Network for Implementing Ecodemocracy
}

\begin{abstract}
This commentary discusses the representation of individuals versus populations human and nonhuman, present and future - in Treves et al.'s proposed trusteeship for futurity. Terminological questions are also discussed.
\end{abstract}

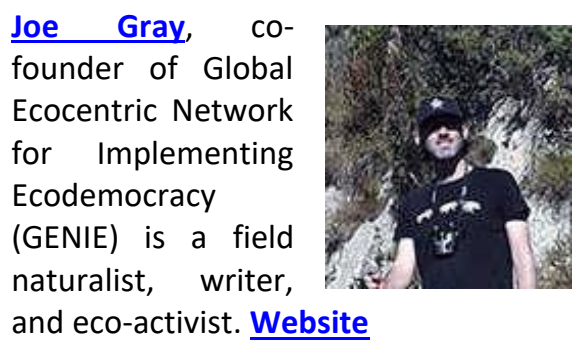

Treves et al. (2018) make a major contribution to levelling "the playing field between humans and non-humans in a very practical sense." Challenging human-centred thinking, they propose practical implementations of justice for all of Earth's beings through a political voice for a broader pool of stakeholders. It is imperative to seek and test remedies against the injustices being endured by all our fellow Earthlings. Instead of miring the project in an academic bog, humans need to behave as plain citizens more than ever before.

The proposal to use trusteeship as a mechanism for expanding the pool of enfranchised beings is interesting and worthy of exploration. The goal of positioning human concerns "alongside, not in front or before," non-human concerns neatly captures the work that lies ahead. As the authors note, potential conflicts between stakeholders need to be addressed as this project gathers momentum. I would like to offer some further observations:

1. Treves et al.'s criticism of the term "ecological" because of the "moral dismissal of individual non-humans" by some ecologists seems akin to dismissing the term "psychological" because of the beliefs of some psychologists.

2. The authors' advocacy for "preserving the planet for future life" risks weakening the case for justice by shifting the focus from the suffering being inflicted on current living beings (which could resonate more with politicians and citizens who need to be convinced) to potential future beings.

3. The strong push to grant representation to human youth risks diluting the need for representing non-humans: Young people, if they reach voting age, will be enfranchised for at least a proportion of their lives (and before that, they will probably have parents who vote with some consideration for their interests). The same cannot be said for a barn owl or a population of marsh frogs. The typical human youth is subject to far less injustice than the typical non-human. 
4. On individuals versus populations: As one of the co-authors of Washington et al. (2018), I do see individual non-humans as being owed moral consideration by humans. However, when one looks beyond iconic wildlife to the much more abundant smaller organisms, such as beetles and wildflowers, it is more helpful to think of populations rather than individuals. In most cases, political enfranchisement of non-humans will require representation of individuals en bloc. Thinking of populations rather than individuals does not "peripheralize" them: it offers some hope of practical action on their behalf.

5. I was confused by the glossary definition of "speciesism" that referred to "varieties of ecocentrism that privilege the interests of human beings while inconsistently reducing other sentient, sapient, and social animals to biological machines, functional units of ecosystems, and resources for our use and abuse." Ecocentrism (as discussed in Curry [2018]) is, by definition, a challenge to this privilege.

6. I am not convinced that "just preservation" is the term to "level the playing field." "Preservation" is a subset of "conservation" and thus not general enough to capture all potential issues. "Earth jurisprudence" and "ecodemocracy" may be more helpful because they are more broadly applicable.

7. Finally, although it is not so relevant to the thread of this discussion, I dispute that "climate change" is "our generations' existential threat to ... all life on Earth." Habitat destruction, habitat fragmentation, and killing of wildlife by humans are the major drivers of the biodiversity crisis (Maxwell et al., 2016).

For further thoughts on how to represent the interests of non-humans in practice, see Gray \& Curry (2019) and Gray et al. (2020).

\section{References}

Curry, P. (2018) Ecological Ethics: An Introduction (updated 2nd edition). Cambridge, UK: Polity Press.

Gray, J., \& Curry, P. (2019). Ecodemocracy and political representation for non-human nature. In: H. Kopnina and H. Washington, eds. Conservation: Integrating Social and Ecological Justice. Cham, Switzerland: Springer, 155-166.

Gray, J., Wienhues, A., Kopnina, H., \& DeMoss, J. (2020) Ecodemocracy: Operationalizing ecocentrism through political representation for non-humans. The Ecological Citizen, 3.

Maxwell, S.L., Fuller, R.A., Brooks, T.M., \& Watson, J.E. (2016). Biodiversity: The ravages of guns, nets and bulldozers. Nature, 536, 143-145.

Treves, A., Santiago-Ávila, F., \& Lynn, W. S. (2019). Just preservation. Biological Conservation, 229, 134-141.

Treves, A., Santiago-Ávila, F., \& Lynn, W. S. (2019). Foreword and rationale for inviting open peer commentary. Animal Sentience 27(1).

Washington, H., Chapron, G., Kopnina, H., Curry, P., Gray, J., \& Piccolo, J. (2018).

Foregrounding ecojustice in conservation. Biological Conservation, 228, 367-374. 